\title{
NOTES FOR AUTHORS
}

Papers submitted for publication in the Bulletin of Entomological Research should be sent, in duplicate, to the Director, C.A.B International Institute of Entomology, 56 Queen's Gate, London SW7 5JR. They must deal with original research concerning insects, mites or ticks of economic importance in the agricultural, medical or veterinary fields; they must be of more than purely local interest, and taxonomic papers will not be accepted unless the organisms dealt with are of definite importance in the field of applied entomology. Review articles may also be submitted, but will normally be by invitation. Papers must not have been published or accepted for publication elsewhere. They will normally be published in order of their receipt in definitive form.

For general guidance on presentation and style, including the preparation of illustrations, contributors are urged to consult Writing Scientific Papers in English. An ELSE-Ciba Foundation Guide for Authors (by Maeve O'Connor \& E. Peter Woodford). 116 pp., Amsterdam, Associated Scientific Publishers, 1975, ISBN 90-219-4035-3.

Text

Papers should be typewritten (double spaced, with ample margins and on one side of the paper only) and a current number of the Bulletin should be consulted for details of style and lay-out. Titles should be as brief as is consistent with clarity. Abbreviations should conform to British Standard 1991, Part I, 1967, and are alike in singular and plural; stops will be used only where ambiguity might occur, e.g. 'in.' not 'in' for inch, but 'in ' ${ }^{2}$ for square inch. Metric units are preferred; if non-metric units are used, metric equivalents should be given at least once in each article.

Tables

Tables should be reduced to the simplest form, and should not be used where text or illustrations give the same information. They should be submitted on separate sheets at the end of the article and must on no account be of a size or form that will not conveniently fit into the page of the Bulletin.

\section{Illustrations}

Line drawings and graphs must be in jet-black indian ink, preferably on Bristol-board or tracing cloth. Graphs may be drawn on paper ruled in pale blue or light grey; paper having green, red, yellow or brown lines should not be used. Any stippling or hatching, as well as any numerals or lettering, on the text-figures must be completed, by the author, in a form suitable for reproduction; this work is not undertaken by the printer. Text-figures, when reproduced, cannot exceed $12.7 \mathrm{~cm}$ in width; if, therefore, the original drawings are larger, the lettering on them must be in proportion, so that it is still legible when reduced; special attention should be paid to the relative scales of lettering and line thicknesses in relation to the figure as a whole. Photographs for reproduction as figures are admissible when they are a real contribution to the text. Captions to figures should be typed on a separate sheet.

\section{Abstract}

Each paper must contain a carefully prepared and accurate informative abstract that shall be complete in itself and intelligible without reference to the text or figures. It should not exceed 250 words, and should be included at the beginning immediately after the title, author and author's affiliation.

\section{References}

References must be based on the name and year system and conform to the present usages of the Bulletin. Titles of journals should be abbreviated as in the 4th edition of The World List of Scientific Periodicals. References to unpublished information should normally be included only in the text-(A. B. Jones, pers. comm.) or (A. B. Jones, Control of sandflies by insecticides. Unpublished report. Ross Institute, London, 1950).

\section{Offprints}

Free copies of offprints are allowed as follows: One author-20 copies, two or more authors- -30 copies. Further copies may be obtained on payment, and the number required should be specified when the paper is submitted. 


\section{BULLETIN OF ENTOMOLOGICAL RESEARCH}

(World List Abbreviation: Bull. ent. Res.)

ISSN 0007-4853

Review article

PAGE

Cowie, R. H., Logan, J. W. M. \& Wood, T. G. Termite (Isoptera) damage and control in tropical forestry with special reference to Africa and IndoMalaysia: a review

\section{Original articles}

MCGeachie, W. J. The effects of mooonlight illuminance, temperature and wind speed on light-trap catches of moths

Malcolm, C. A. \& Boddington, R. G. Malathion resistance conferred by a carboxylesterase in Anopheles culicifacies Giles (species B) (Diptera: Culicidae)

Tahhan, O. \& van Emden, H. F. Biology of Bruchus dentipes Baudi (Coleoptera: Bruchidae) on Vicia faba and a method to obtain gravid females during the imaginal quiescence period

TahHan, O. \& van EMden, H. F. Resistance of faba bean, Vicia faba, to Bruchus dentipes Baudi (Coleoptera: Bruchidae)

Way, M. J., Cammell, M. E., Bolton, B. \& Kanagaratnam, P. Ants (Hymenoptera: Formicidae) as egg predators of coconut pests, especially in relation to biological control of the coconut caterpillar, Opisina arenosella Walker (Lepidoptera: Xyloryctidae), in Sri Lanka

Braun, A. R., Guerrero, J. M., Bellotti, A. C. \& Wilson, L. T. Within-plant distribution of Mononychellus tanajoa (Bondar) (Acari: Tetranychidae) on cassava: effect of clone and predation on aggregation

Allsopp, P. G. \& Bull, R. M. Spatial patterns and sequential sampling plans for melolonthine larvae (Coleoptera: Scarabaeidae) in southern Queensland sugarcane

Pegram, R. G., Zivkovic, D. \& Jongejan, F. Ticks (Acari: Ixodoidea) of the Yemen Arab Republic. II. The Rhipicephalus sanguineus (Latreille) group ...........

WiLson, A. G. L. \& Morton, R. Some factors affecting the reliability of pheromone traps for measurement of the relative abundance of Helicoverpa punctigera (Wallengren) and $H$. armigera (Hübner) (Lepidoptera: Noctuidae)

JACKAI, L. E. N. A laboratory procedure for rearing the cowpea coreid, Clavigralla tomentosicollis Stål (Hemiptera), using dry cowpea seeds

Walker, A. K. Synonymy of two Apanteles species (Hymenoptera: Braconidae) parasitizing the coconut flat moth, Agonoxena argaula Meyrick (Lepidoptera: Agonoxenidae)

Asche, M. \& Wilson, M. R. The three taro planthoppers: species recognition in Tarophagus (Hemiptera: Delphacidae)

Hossain, M. I., CurTis, C. F. \& HeEkin, J. P. Assays of permethrin-impregnated fabrics and bioassays with mosquitoes (Diptera: Culicidae)

Padgham, D. E., Woodhead, S. \& Rapusas, H. R. Feeding responses of the brown planthopper, Nilaparvata lugens (Stål) (Hemiptera: Delphacidae), to resistant and susceptible host-plants

Hall, M. J. R. \& LANGLEY, P. A. The responses of individual males in an isolated population of Glossina morsitans morsitans Westwood (Diptera: Glossinidae) to pheromone-baited decoy 'females'

WALL, R. Sexual responses of males of Glossina morsitans morsitans Westwood and G. pallidipes Austin (Diptera: Glossinidae) to traps and targets in the field .

(C) C.A.B International, 1989

All rights reserved. No part of this publication may be reproduced, in any form or by any means, electronically, mechanically, by photocopying, recording or otherwise, without prior permission of the copyright owner. 